Maurice A. Deane School of Law at Hofstra University Scholarly Commons at Hofstra Law

Hofstra Law Student Works

2013

\title{
Adaptation to Climate Change and the Everglades Ecosystem
}

Frank Piccininni

Follow this and additional works at: http://scholarlycommons.law.hofstra.edu/

hofstra_law_student_works

Part of the Environmental Law Commons

\section{Recommended Citation}

Environmental Claims Journal, 26(1):63-83, 2014

This Article is brought to you for free and open access by Scholarly Commons at Hofstra Law. It has been accepted for inclusion in Hofstra Law Student Works by an authorized administrator of Scholarly Commons at Hofstra Law. For more information, please contact lawcls@hofstra.edu. 


\title{
Adaptation to Climate Change and the Everglades Ecosystem
}

\author{
FRANK PiCCININNI
}

\begin{abstract}
Water management, development, and farming continue to degrade the structure and function of the Florida Everglades. Global climate change is expected to exacerbate these anthropogenic impacts. This article explores the historical and current adulteration of the Everglades, reviews the expected effects of climate change on the ecosystem, and recommends an amendment to the farm bill to support the implementation of adaptive management to increase climate resilience.
\end{abstract}

\section{INTRODUCTION}

The Florida Everglades is a vast and dynamic landscape characterized by pulsing flows of water, iconic wildlife, tree islands, and a complex mosaic of floral assemblages. ${ }^{1}$ The Everglades ecosystem was referred to as Payhay-okee, or grassy lake, by the Seminole Indians and has been designated as a World Heritage Site, a Ramsar Convention Wetland of International Importance, and a World Biosphere Reserve. ${ }^{2}$ Unfortunately, the "grassy lake" has been transformed into a highly managed network of canals and water management structures designed to reclaim the Everglades for agricultural use and settlement. ${ }^{3}$ Recognizing the deleterious impact of water

Frank Piccininni works with the North Shore Land Alliance, Inc., and is a Professor William R. Ginsberg Memorial Fellow in Environmental Law at Maurice A. Deane School of Law at Hofstra University.

Address correspondence to Frank Piccininni, North Shore Land Alliance, Inc., 151 Post Rd., Old Westbury, NY 11568. E-mail: Piccininni.Frank@gmail.com

${ }^{1}$ See Marjory S. Douglas, The Everglades: River of Grass (1947; Sarasota, Fla.: Pineapple Press, 1997) ("They are unique also in the simplicity, the diversity, the related harmony of the forms of life they enclose. The miracle of the light pours over the green and brown expanse of saw grass and of water, shining and slowmoving below, the grass and water that is the meaning and central fact of the Everglades of Florida. It is a river of grass.").

2 "Everglades is Internationally Significant," http://www.nps.gov/ever/parknews/internationaldesig nations.htm (accessed April 12, 2012).

${ }^{3}$ See generally Stephen S. Light and J. Walter Dineen, "Water Control In The Everglades: A Historical Perspective," in Everglades: The Ecosystem and Its Restoration, eds. Steven M. Davis and John C. Ogden (Delray Beach, Fla.: St. Lucie Press, 1994) (describing the history of water management in the Everglades), 47-84. 
management in the Everglades, the state of Florida and the U.S. federal government have agreed to an ambitious attempt to revive natural flow regimes called the Comprehensive Everglades Restoration Plan (CERP). ${ }^{4}$ Policymakers and researchers are realizing that conservation and management planning efforts, including the CERP, must incorporate the reality of global climate change. 5

Wetlands such as the Everglades ecosystem are particularly vulnerable to changes in water quality, water quantity, and hydrological regimes; all of which are expected to be adversely impacted by climate change. ${ }^{6}$ Given the internationally recognized importance of the Everglades ecosystem and the extent of the federal and state's investment in the CERP, it behooves the relevant administrative authorities to adapt their restoration efforts to increase resilience to climate change. ${ }^{7}$ Accordingly, CERP planners have begun to incorporate projected short- and long-term impacts of climate change into their planning. These efforts are, however, in the preliminary stages and it is has been difficult to evaluate their effectiveness. ${ }^{8}$

Scholars have recommended that adaptive management should be used to respond to the uncertainty associated with climate change. ${ }^{9}$ Adaptive management is an iterative process in which information garnered from past

\footnotetext{
4114 Stat. 2681 (seeking to "restore, preserve, and protect the South Florida ecosystem while providing for other water-related needs of the region, including water supply and flood protection"); 62 Stat. 1176 (mandating the construction of storm water treatment areas for "hydroperiod restoration" according to specified deadlines). The National Research Council, an independent scientific review board charged with monitoring the Everglades restoration, has reported that, twelve years into CERP, little progress towards restoring the hydrology of the central Everglades has been made. Stumbling blocks include scientific uncertainty, congressional inaction, local conflicts between species management and restoration management, and water quality issues. Commission on Independent Scientific Review of Everglades Restoration Progress, National Research Council, Progress toward Restoring the Everglades: Fourth Biennial Review 8 (2012).

5 See Robert L. Glicksman, "Governance of Public Lands, Public Agencies, And Natural Resources," in The Law of Adaptation to Climate Change, U.S. and International Aspects, eds. Michael B. Gerrard and Katrina F. Kuh (Chicago: American Bar Association Publishing, 2012), 446 -447 (discussing an "adaptation policy vacuum" and a lack of coordinated efforts among agencies charged with management of land); see also Potential Ecological Consequences of Climate Change in South Florida and the Everglades (South Florida Natural Resource Center, National Park Service, 2008) 22 (finding that the variability associated with climate change necessitates the use of adaptive research and management techniques to achieve the goal of restoring the Everglades ecosystem).

${ }^{6}$ See Kevin L. Erwin, "Wetlands and Global Climate Change: The Role of Wetland Restoration in a Changing World," Wetlands Ecology and Management 17 (2009): 71 (describing the vulnerability of wetlands to various ecosystem stressors associated with rising global temperatures); see also International Governmental Panel on Climate Change, "Climate Change 2007: Synthesis Report," http://www.ipcc.ch/pdf/assessment-report/ar4/syr/ar4_syr.pdf (maintaining that climate change will likely lead to increased frequency of floods, droughts, runoff, and significant precipitation events).

${ }^{7}$ See South Florida Natural Resources Center, supra note 5, 22.

${ }^{8}$ See Committee on Independent Scientific Review of Everglades Restoration Progress, National Research Council, Progress Toward Restoring The Everglades: The Third Biennial Review 227 (2010).

${ }^{9}$ See e.g., Robert L. Fischman and Jillian R. Rountree, "Adaptive Management," in eds. Gerrard and Kuh, The Law of Adaptation to Climate Change, 27-29.
} 
management efforts is explicitly incorporated into future decision making. ${ }^{10}$ Yet, adapting the CERP to climate change is difficult because of the political and legal complexity of regulations regarding the Everglades. ${ }^{11}$ Adaptive management in the Everglades must work within the complex management criteria mandated by law and engage the participation of contentious stakeholders such as Everglades farmers and environmentalists. ${ }^{12}$

This article seeks to help incorporate adaptive management strategies into the CERP to improve climate resilience. Specifically, this article recommends that Congress amend the farm bill ${ }^{13}$ to encourage Everglades farmers to adapt to the reality of climate change by restoring agricultural fields to native habitat. Part II provides the context of the recommendations by reviewing the baseline conditions of the Everglades ecosystem including efforts to manage water, the current legal apparatus governing Everglades agriculture, and the projected impact of climate change on the system. Part III then provides a spatially explicit adaptive management plan for Everglades farmers, and describes amendments to the farm bill that support efforts to adapt Everglades farming practices to the reality of climate change. To facilitate this process, I argue that a direct subsidy should be extended to Everglades farmers who plant and adaptively manage stands of native vegetation (Everglades Custard Apple Restoration Area; see Fig. 1) in order to increase water quality and climate resilience.

\section{FARMING AND WATER MANAGEMENT IN THE EVERGLADES}

The history of the Everglades is often described as consisting of two stages, i.e., before and after drainage. ${ }^{14}$ Draining of the Everglades has impacted patterns of natural hydrology, ${ }^{15}$ damaged the structure and

\footnotetext{
${ }^{10} \mathrm{Id}$.

${ }^{11}$ See Alfred R. Light, "Tales of the Tamiami Trail: Implementing Adaptive Management in Everglades Restoration," Journal of Land Use and Environmental Law 22 (2006): 59, 96. The effective implementation of adaptive management in CERP has been hindered by, inter alia, conflicting agency mandates, regulatory ossification, legal challenges, and inefficient mechanisms to incorporate public input. Id., 96.

12 See J. B. Ruhl and Robert L. Fischman, "Adaptive Management in the Courts," Minnesota Law Review 95 (2010): 424, 427.

13 Food, Conservation, and Energy Act of 2008, 7 USCA $\S \S 8701-8793$.

14 See e.g., John C. Ogden, "Everglades Ridge and Slough Conceptual Ecological Model," Wetlands 25 (2005): 810, 810 .

15 See $i d$., 810 (describing changes in the "depth, distribution, and duration" of water and its negative effects on the Ridge and Slough region of the Everglades); see also Judson W. Harvey and Paul V. McCormick, "Groundwater's Significance to Changing Hydrology, Water Chemistry, and Biological Communities of a Floodplain Ecosystem, Everglades, South Florida, USA," Hydrogeology Journal 17 (2009): 185, 185 (detailing the degradation of groundwater due to the installation of canals).
} 


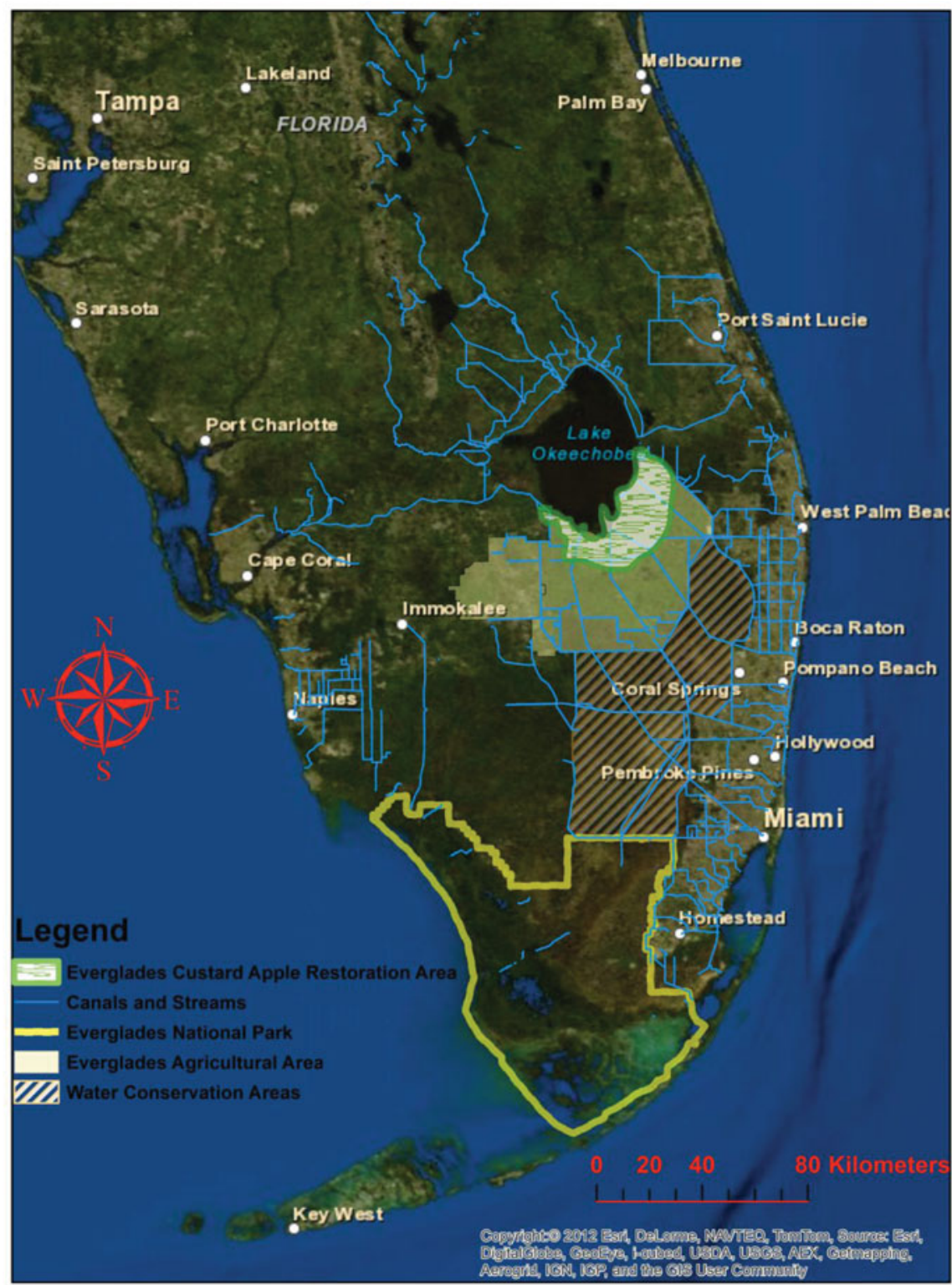

FIgURE 1. A map of the Everglades ecosystem and the proposed Everglades Custard Apple Restoration Area. The map was created with ArcGIS version 10.1. All shapefiles, with the exception of the boundaries of the Everglades Custard Apple Restoration Area, are freely available on the website of the South Florida Water Management District. The shapefile of the proposed Everglades

Custard Apple Restoration Area is available upon request from the author. See Geographical Information Systems, http://www.sfwmd.gov/portal/page/portal/levelthree/GIS (accessed April 12, 2013). Basemap used by permission. Copyright (C) 2012 Esri, Esri, DeLorme, NAVTEQ, TomTom, Source: Esri DigitalGlobe, GeoEye, icubed, USDA, USCS, AEX, Getmapping, Aerogrid, IGN, IGP, and the GIS User Community (color figure available online). 
function of Everglades flora, ${ }^{16}$ and had a pernicious impact on the Everglades fauna. ${ }^{17}$ Moreover, mitigating water management on the ecosystem is expected to become more difficult as global warming progresses. ${ }^{18}$ Accordingly, researchers and policymakers have sought to address these issues with adaptive management. ${ }^{19}$

Adaptive management considers the landscape to be the result of complex and ongoing biological and sociopolitical interactions. ${ }^{20}$ Adaptive managers seek to develop plans that are as dynamic as the system for which they are designed. ${ }^{21}$ This interdisciplinary framework is particularly difficult to implement in the context of the Everglades restoration because of large-scale water management efforts and local resistance to Clean Water Act regulation. ${ }^{22}$ Any effort to adapt the CERP to climate change must explicitly consider the history and current status of water management and regulation of Everglades agricultural areas. Thus, the following provides a detailed description of past and present water management efforts, summarizes the current legal apparatus governing agriculture in the Everglades, and reviews the expected impact of climate change on the Everglades ecosystem.

\section{A. From the Swamp and Overflowed Lands Act to the South Florida Water Management District}

The natural hydrology of the Everglades was influenced by topography, precipitation, and low velocity pulses of water overflowing from Lake Okeechobee (i.e., sheet flow). ${ }^{23}$ Due to seasonal inundation, the Everglades could not support agriculture or settlement and was, therefore, considered of little use. In 1850 the U.S. Congress passed the Swamp and Overflowed Lands

\footnotetext{
16 See M. S. Ross et al., "Vegetation: Environment Relationships and Water Management in Shark Slough, Everglades National Park," Wetlands Ecology and Management 11 (2009): 291, 291 (concluding that compartmentalization and water management practices impact natural gradients of vegetation); see also Yegang Wu et al., "The Spatial Pattern and Dispersion of Lygodium microphyllum in the Everglades Wetland Ecosystem," Biological Invasions 8 (2006): 1483, 1483 (finding that approximately 11.6 percent of tree islands in the Loxahatchee National Wildlife Refuge has been invaded by Old World Climbing Fern); Paul R. Wetzel et al., "Landscape Analysis of Tree Island Head Vegetation in Water Conservation Area 3, Florida Everglades," Wetlands 28 (2008): 276, 277 (explaining that increased drainage leads to fires that destroy tree island vegetation).

17 See e.g., G. Thomas Bancroft et al., "Relationships among Wading Bird Foraging Patterns, Colony Locations, and Hydrology in the Everglades," in eds. Davis and Ogden, Everglades, 615-652 (concluding that water management has degraded wading bird foraging and nesting habitats).

18 See Leonard G. Pearlstine, "A Review of the Ecological Consequences and Management Implications of Climate Change for the Everglades," Journal of the North American Benthological Society 29 (2010): 1510, 1521 ("The ecological consequences of climate change will reshuffle vegetation and wildlife composition, distributions, and abundance in unpredictable ways").

${ }^{19}$ See South Florida Natural Resources Center., supra note 5, 22.

20 See Fischman and Rountree, supra note 9, 23.

21 Id.

${ }^{22}$ See Light and Dineen, supra note 3, 96.

23 Ogden, supra note 14,810 .
} 
Act in order to encourage the several states to reclaim wetlands that were not suitable for agriculture due to flooding. ${ }^{24}$ Florida was admitted into the union five years later and the Florida legislature resolved to drain the Everglades to profit from what they believed to be "wholly valueless in consequence of being covered by water. .." 25 Accordingly, Congress dispatched an attorney, Buckingham Smith, to study the feasibility of Everglades drainage. Mr. Smith reported that drainage was possible and that without drainage, the Everglades was only suitable as a "haunt of noxious vermin" or a "resort of pestilent reptiles." 26

State level water management in south Florida began in 1856 when the Board of Trustees of the Internal Improvement Fund of the state of Florida resolved to take control of large portions of the Everglades. ${ }^{27}$ The state encouraged private landowners to "improve" the land by draining and making it suitable for agriculture. One notable land transfer was the purchase of 4 million acres for $\$ 1$ million by Hamilton Disston. ${ }^{28}$ Disston's efforts resulted in an 11-mile-long canal and the drainage of large tracts of the Everglades. ${ }^{29}$

The wholesale modification of Everglades hydrology began in earnest in 1907 when the Florida legislature, urged by then-governor Napoleon Bonaparte Broward, passed the organic statute for the Everglades Drainage District. ${ }^{30}$ Funded by the levying of drainage taxes, the Everglades Drainage District dissected the Everglades with 433 miles of canal, constructed fiftyfour miles of levees and fourteen canal locks. ${ }^{31}$

249 Stat. 519-520.

25 S. Doc. No. 87, 34 (1911).

26 See id., 54 .

${ }^{27}$ Board of Trustees of the Internal Improvement Trust Fund (Florida 1856), http://digitalcollections. fiu.edu/iif/volumes/volume1/FI06013201_body.pdf ("all the swamp and overflowed lands selected by the State shall be subject to private entry on the terms heretofore fixed from and after this date"). The Board of Trustees of the Internal Improvement Trust Fund is now comprised of the governor and cabinet of Florida and staffed by the Florida Department of Environmental Protection. See Florida Department of Environmental Protection, http://www.dep.state.fl.us/lands/statelands_cont.htm (accessed April 13, 2013).

28 Board of Trustees of the Internal Improvement Trust Fund (Florida 1881), http://digitalcollections. fiu.edu/iif/volumes/volume3/FI06013203_body.pdf (setting forth the payment plan for the purchase of portions of the everglades).

${ }^{29}$ Light and Dineen, supra note 3, 53. Disston's ambition to drain the Everglades was thwarted by an economic depression that destroyed his enterprise and eventually caused him to take his own life. Id.

301913 Florida Laws 129 ("for the purpose of draining and reclaiming the lands hereinafter described and protecting the same from the effects of water, for agricultural and sanitary purposes, and for the public convenience and welfare, and for the public utility and benefit, a drainage district is hereby established to be known and designated as the Everglades Drainage District").

311913 Florida Laws 160 (levying a tax of five cents per acre of Everglades land to finance the draining of the Everglades); See also Board of Trustees of the Internal Improvement Trust Fund (Florida1907), http://digitalcollections.fiu.edu/iif/volumes/volume7/FI06013207_body.pdf (“...the work done has been something marvelous, and the achievements far beyond the most sanguine or hopeful expectation of those in charge of its inauguration"); G. H. Snyder and J. M. Davidson, "Everglades Agriculture: 
In 1929 two hurricanes killed approximately 2,500 people on the south shore of Lake Okeechobee, prompting the Florida legislature to create the Okeechobee Flood Control District. ${ }^{32}$ Supported by U.S. Army Corps of Engineers (Corps), the Okeechobee Flood Control District installed hurricane gates and built a large dike along the southern rim of Lake Okeechobee. ${ }^{33}$

Hurricanes once again decimated south Florida from 1947-1948, causing a great deal of flooding throughout the entire Everglades ecosystem. ${ }^{34}$ After the second flood the U.S. Congress responded by enacting the Flood Control Act of 1948, which authorized a renewed effort to drain the Everglades called the Central and Southern Florida Project for Flood Control and Other Purposes (C\&SF) ${ }^{35}$ To better coordinate state level participation in the C\&SF, the Florida legislature subsumed the Everglades Drainage District and the Okeechobee Flood Control District into one agency called the Central and Southern Florida Flood Control District. ${ }^{36}$ The Central and Southern Florida Flood Control District was later renamed the South Florida Water Management District (WMD). The WMD is currently the agency administering water management in the Everglades. ${ }^{37}$

The WMD and the Corps administered the C\&SF by dredging existing canals, creating levees, employing pumps, and managing sheet flow with enormous impoundments called water conservation areas. ${ }^{38}$ Although the state and federal regulatory agencies successfully dealt with flooding in the Everglades, the WMD continuously struggles to balance environmental issues associated with water management and human land use. ${ }^{39}$

\section{B. Law, Agriculture, and Water Quality in the Everglades Ecosystem}

Adaptation of the CERP to climate change necessitates consideration of the current legal regime governing agriculture and water quality in the Everglades. One of the first ambitions of the C\&SF was to control flooding in this area to take advantage of the relatively fertile soil and create the Everglades

Past, Present, and Future," in eds. Davis and Ogden, Everglades, 615-652 (describing the extent of the drainage work completed by the Everglades Drainage district).

32 See Light and Dineen, supra note 3, 57 (demonstrating the spatial extent of area devastated by hurricanes in 1926 and 1928).

33 Id., 55 .

34 Id., 58 .

3562 Stat. 1171 (1948).

361949 Florida Laws 514 (1949).

${ }^{37}$ Florida Stat. Ann. $\S 373.069$ (West 2009) (setting forth the current state level administrators of water management in Florida).

38 See Light and Dineen, supra note 3, 63-67.

${ }^{39}$ See Alfred R. Light, "Beyond the Myth of Everglades Settlement: The Need for A Sustainability Jurisprudence," Tulsa Law Review 25344 (2008) (finding that the current adaptive management plan in the Everglades fails to focus on dispute resolution). 
Agricultural Area (EAA). ${ }^{40}$ Farmers utilizing the EAA supplemented the CS\&F by excavating their own ditches that were connected to major canals. ${ }^{41}$ This on-farm water control infrastructure allows farmers to control water levels on their fields in order to deal with flooding and drought but also contributes to water quality issues. ${ }^{42}$ The following details the evolution of water quality and agricultural regulation in the Everglades in order to underscore the legal and political complexity of adaptive management planning in the Everglades.

Currently, farmers in the EAA predominately grow sugarcane, vegetables, rice, and sod. ${ }^{43}$ The farming of sugarcane in the Everglades has been particularly profitable because sugar plants are flood tolerant, ${ }^{44}$ and the sugar industry has a long history of benefiting from governmental price controls and subsidies. ${ }^{45}$

Farmers in the EAA, especially the sugar corporations, have not enjoyed a complimentary reputation for environmental responsibility and stewardship. ${ }^{46}$ This is due to the environmental impact that farming has on the Everglades ecosystem. ${ }^{47}$ The Everglades are naturally an oligotrophic (i.e., nutrient poor) ecosystem; runoff of nutrients associated with agricultural practices has adversely impacted the unfarmed portions of the Everglades. ${ }^{48}$

${ }^{40}$ See Soil Conservation Service, United States Department of Agriculture, Soil Survey of Palm Beach County Area, Florida 41 (1978), http://soildatamart.nrcs.usda.gov/manuscripts/FL611/0/ Palm_Beach.pdf (finding that once drained, Torrey muck (the name of the soil on the south shore of Lake Okeechobee) is "well suited" for agriculture and, notably, that there are no longer any portions of this soil "with native vegetation").

41 See Snyder and Davidson, supra note 31, 99-100.

42 See Timothy A. Lang et al., "Environmental and Management Factors that Influence Drainage Water P Loads from Everglades Agricultural Area Farms of South Florida," Agriculture, Ecosystems and Environment 138 (2010): 170, 170. During the dry season, water is pumped from Lake Okeechobee to irrigate the farms, whereas during the wet season, water is pumped off the farms into the Everglades and back-pumped into Lake Okeechobee. $I d$.

43 Id.

44 See Barry Glaz et al., "Sugarcane Cultivar Response to High Summer Water Tables in the Everglades," Agronomy Journal 94 (2002): 624, 624-629 (using field experiments to demonstrate that flooding had little effect on the yield of Saccaharum spp.).

45 See Jeff Leblanc, "A Sweet Deal for Sugar," Missouri Environmental Law and Policy Review 15 (2007): 67, 69 (reviewing various subsidies enjoyed by sugar farmers); see also Katherine Mohr, “How Sweet It Isn't: Big Sugar's Power Politics and the Fate of the Florida Everglades," Florida A\&M University Law Review 7 (2012): 329, 338 (finding that tax laws have protected sugar producers since 1789).

${ }^{46}$ See $i d ., 331$ ("Despite continued and varying attempts to try and stop the degradation of the Everglades, it seems that no law has been successful; the destruction continues 'almost unabated,' while Big Sugar and agriculture reap the benefits").

47 Snyder and Davidson, supra note 31, 110-112 (describing the "vilification" of the sugar industry).

${ }^{48}$ See Paul V. McCormick et al., "Influence of Changing Water Sources and Mineral Chemistry on the Everglades Ecosystem," Critical Reviews in Environmental Science and Technology 41 (2011): 28, 39 (demonstrating a decreased concentration of phosphorus with increased distance from canals); see also Steven M. Davis, "Phosphorus Inputs and Vegetation Sensitivity in the Everglades," in eds. Davis and Ogden, Everglades, 615-652 (documenting the conversion of native sawgrass marshes into invasive cattail monocultures near anthropogenic input of phosphorus). 
Eutrophication of the Everglades has led to an abundance of litigation, an amendment to the Florida State Constitution, ${ }^{49}$ the enactment of a major statutory scheme, and numerous state regulations. ${ }^{50}$ Attempts to use the Clean Water Act to improve water quality have been cumbersome because farmers and environmentalists have fought protracted legal battles over the act's application. ${ }^{51}$ Moreover, onerous regulatory burdens and political pressure cause the U.S. Environmental Protection Agency (USEPA) and the WMD to be reluctant to enforce water quality standards mandated by the Clean Water Act. ${ }^{52}$ Ultimately, it took the intervention of environmental advocates, such the Miccosukee Tribe of Indians and the Friends of the Everglades, to compel the USEPA and the WMD to enforce the water quality standards of the Clean Water Act. ${ }^{53}$

Modern Everglades litigation began in 1988. The U.S. attorney filed suit against the WMD and the Florida Department of Environmental Regulation ${ }^{54}$ in federal court, ${ }^{55}$ alleging that the defendants were in violation of water quality standards promulgated pursuant to state implementation of the Clean Water Act. ${ }^{56}$ The parties in this lawsuit reached an agreement, memorialized as a consent decree in 1992, which mandated the reduction of nutrient input into the Everglades. ${ }^{57}$ To implement the decree, the Florida legislature passed the Everglades Protection Act, thereby delegating authority to the WMD to implement the Surface Water Improvement and Management Plan (SWIM Plan). ${ }^{58}$

${ }^{49}$ Florida Const. art. II, $\S 7$; Florida Const. art. X, § 17. In 1995 the people of the state of Florida voted to amend the Florida State Constitution to hold the farmers of the EAA responsible for the destruction and degradation of the Everglades. The supreme court of Florida, however, issued an advisory opinion holding, inter alia, that the so-called "polluter pays" amendments were not self-executing and that existing statutes remained in effect until the passage of implementing legislation. Advisory Opinion to Governor-1996 Amendment 5 (Everglades), 706 So. 2d 278, 283 (Florida 1997).

${ }^{50}$ See Keith W. Rizzardi, “A Recent History of Everglades Regulation and Litigation," Florida Bar Journal, March 2001: 18, 25.

51 See generally Alfred R. Light, "Miccosukee Wars in the Everglades: Settlement, Litigation, and Regulation to Restore an Ecosystem,” St. Thomas Law Review 13 (2001): 729.

52 Id.

53 Id., 731.

54 The Florida Department of Environmental Regulation later became known as the Florida Department of Environmental Protection. Rizzardi, supra note 50, 19.

55 U.S. v. S. Florida Water Mgmt District, No. 88-1886 CIV-HOEVELER (S.D. Florida).

56 Under the statutory scheme of the Clean Water Act, states are predominately responsible for developing and implementing water quality standards. Each state classifies each body of water's intended use, and then promulgates qualitative or quantitative standards to protect such use. These plans are then reviewed and approved by the U.S. Environmental Protection Agency. See generally 33 USCA $\S 1313$ (West).

57 See U.S. v. S. Fla. Water Mgmt. District, 88-1886-CIV-WMH (order entering settlement agreement as consent decree), http://www.law.miami.edu/library/everglades/litigation/federal/usdc/88_1886/ orders/1205_847FSupp1567.html\#I (agreeing to the creation of storm water treatment areas and the implementation of various nutrient control programs).

58 See 1991 Florida Laws Ch. 91-80 ("It is the intent of the Legislature to facilitate the surface water improvement and management process, to assist the district and the Department of Environmental 
The implementation of the SWIM Plan was fraught with controversy due to opposition from farmers. ${ }^{59}$ Accordingly, federal and state agencies and agricultural groups convened in an attempt to end the litigation with a document called the statement of principles. ${ }^{60}$ Parties to the statement of principles pledged to end litigation, increase water quality, commit to a detailed implementation schedule, and to adopt best management practices. In 1994, to codify many of the pledges included in the statement of principles, the Florida legislature amended the Everglades Protection Act and renamed it the Everglades Forever Act. Notably, the Everglades Forever Act mandated the implementation of best management plans, ${ }^{61}$ levied an agricultural privilege tax, ${ }^{62}$ extended a compliance period through 2006 , and authorized the construction of storm water treatment areas to treat runoff from the EAA. ${ }^{63}$

A little over a month after the enactment of the Everglades Forever Act, the Miccosukee Tribe of Indians of Florida (Miccosukee) notified the USEPA that the act changed Florida's water quality standards and created a mandatory duty of review by the USEPA. ${ }^{64}$ In an attempt to force review, the Miccosukee brought an action under the citizen suit provision of the Clean Water Act, in which the U.S. Sugar Corp., Sugar Cane Growers Cooperative of Florida, and the Secretary of Florida's Department of Environmental Protection (DEP) intervened. ${ }^{65}$ The district court held that the Everglades Forever Act indeed changed the water quality standards, found the USEPA's decision to allow a twelve-year compliance period arbitrary and capricious, and remanded the case back to the USEPA to decide if the changes to Florida's water quality standards were in violation of the Clean Water Act. ${ }^{66}$

Regulation in the performance of their duties and responsibilities, and to provide funding mechanisms which will contribute to the implementation of the strategies incorporated in the Everglades Surface Water Improvement and Management Plan or contribute to projects or facilities determined necessary to meet water quality requirements established by rulemaking or permit proceedings").

59 See Miccosukee Tribe of Indians of Florida v. United States, 95-0533-CIV-DAVIS, 1998 WL 1805539 60 (S.D. Fla. Sept. 14, 1998) (finding that thirty-six lawsuits were filed challenging the clean up plan).

61 See 1994 Florida Laws Ch. 94-115 (Best management plans were to be "determined by the district, in cooperation with the department, based on research, field-testing, and expert review, to be the most effective and practicable, including economic and technological considerations, on-farm means of improving water quality in agricultural discharges to a level that balances water quality improvements and agricultural productivity").

${ }^{62} I d$. The legislature determined that practicing agriculture in the Everglades was a privilege and constituted a reasonable basis for the imposition of an Agricultural Privilege Tax consisting of 63 Id. $\$ 24.89-\$ 35.00 /$ acre, depending on when the tax notice was mailed. Id.

${ }^{64}$ See Miccosukee Tribe of Indians of Florida v. United States, E.P.A., 105 F.3d 599, 601 (11th Cir. 1997).

65 Id. The district court originally dismissed the complaint after determining that subject matter jurisdiction was lacking. On appeal, the U.S. Court of Appeals for the 11th Circuit reversed the district court decision regarding subject matter jurisdiction and remanded to decide the case on the merits. Id.

${ }^{66}$ See Miccosukee Tribe of Indians of Florida v. United States, 95-0533-CIV-DAVIS, 1998 WL 1805539 (S.D. Fla. Sept. 14, 1998), 19 (holding that allowing farmers to discharge phosphorus was in violation 
In 2003 the Florida Legislature once again amended the Everglades Forever Act and set the default effluent limit of phosphorus at $10 \mathrm{ppb}$ (parts per billion) unless the DEP adopted numeric criterion for phosphorus discharge from the Everglades that would not "cause an imbalance in the natural populations of flora and fauna."67 Pursuant to the amended Everglades Forever Act, the DEP initiated rulemaking to develop the so-called phosphorus rule, and submitted portions of the rule to the USEPA for review. The USEPA subsequently approved the phosphorus rule on January $24,2005{ }^{68}$ Judge Gold of the Southern District of Florida found that USEPA's decision to approve the phosphorus rule was arbitrary and capricious, and issued a summary judgment that required the immediate enforcement of the $10 \mathrm{ppb}$ standard. ${ }^{69}$

After inaction by the USEPA and the WMD, the Miccosukee and the Friends of the Everglades then filed a motion for contempt or to otherwise compel in the Southern District of Florida. ${ }^{70}$ In a detailed finding of fact issued in 2010, Judge Gold held that although the state of Florida and the U.S. have spent considerable resources constructing storm water treatment areas, they only partially mitigate pollution of phosphorus from the EAA. ${ }^{71}$ Thus, he found the USEPA in contempt of the summary judgment order and in violation of the Clean Water Act. ${ }^{72}$

In 2011 the USEPA filed a motion in the Southern District of Florida to modify the injunction granted in the 2010 order. $^{73}$ The USEPA sought to enhance water quality by modifying existing NPDES permits to incorporate

of narrative standards set forth in the Everglades Forever Act was a "de facto suspension of, and therefore a change in, water quality standards").

672003 Florida Laws 2003-12.

68 Id.

${ }^{69}$ See Miccosukee Tribe of Indians of Florida v. United States, 04-21448-CIV, 2008 WL 2967654 (S.D. Fla. July 29, 2008), 1 (finding that the USEPA turned a "blind eye" to the Everglades Forever Act and the regulations promulgated thereunder and simply read "words of specific sections" rather than "connecting the dots to analyze its true effect").

70 Miccosukee Tribe of Indians of Florida v. United States, 706 F. Supp. 2d 1296, 1298 (S.D. Fla. 2010) modified in part, 04-21448-CIV, 2011 WL 1624977 (S.D. Fla. Apr. 26, 2011).

${ }^{71}$ Id. Citing a 2005 USEPA study, Judge Gold noted that the spatial area of the Everglades degraded by phosphorus increased from 33.7 percent to 49.3 percent from 1995-2005. Moreover, testimony at the contempt hearing revealed that five storm water treatment areas had no effluent limits in effect at all. He maintained that the state of Florida was "loosening the standards of compliance" by implementing moderating provisions that pushed the target date of compliance to 2016. Id.

72 Id., 1296.

${ }^{73}$ Miccosukee Tribe of Indians of Florida v. United States, 04-21448-CIV, 2011 WL 1624977 (S.D. Fla. Apr. 26, 2011) ("It is time now for this next significant step to occur. The EPA has represented that it wants to act. It must be given the opportunity to do so. The EPA may well have to enforce the objectives as set forth in the Amended Determination, as it has recently stated it would, through further administrative and court actions-which are apparently likely since the opposing parties and interveners are even now presently before the Eleventh Circuit seeking yet another set of appeals on various orders in this litigation."). 
water-quality-based effluent limits and pursuing administrative action against parties that were violating those limits. ${ }^{74}$ The USEPA and the WMD have developed a water quality regulatory plan that includes the creation of new storm water treatment areas over a twelve-year time frame. ${ }^{75}$ The state of Florida and the USEPA are currently working to promulgate water quality criteria that comply with the Clean Water Act, but water quality in the Everglades is far from a settled matter. ${ }^{76}$

Scientists believe that the success of the Everglades restoration is dependent on "getting the water right." 77 Getting the water right, however, will become increasingly difficult due to the impacts of global climate change. ${ }^{78}$ The litigious history of the Clean Water Act's application in the Everglades suggests that implementing adaptive management will be difficult due to tension between environmentalists and EAA farmers. ${ }^{79}$ Farm bill incentive measures to improve water quality as an adaptation to climate change may reduce conflict by aligning the interests of farmers and environmental advocates. ${ }^{80}$

\section{The Projected Impacts of Climate Change on the Everglades Ecosystem}

According to the Intergovernmental Panel on Climate Change (IPCC), the warming of our climate system is unequivocal. ${ }^{81}$ Scientists also find it likely that extreme weather events, such as heat waves and heavy precipitation, have become more frequent and intense over the last fifty years. ${ }^{82}$ Moreover, regional climate change models predict that air temperature in southern Florida will rise $3-5^{\circ} \mathrm{F}$ by the end of the century. ${ }^{83}$ This increase in temperature is likely to correspond with: (1) a decrease of precipitation in all seasons but for the fall; (2) more frequent and destructive fires associated with drought; (3) flooding associated with intense, frequent hurricanes; (4) saltwater intrusion as a result of rising sea level; and (5) changes in the hydrological

${ }^{74} \mathrm{Id}$.

75 See Committee on Independent Scientific Review of Everglades Restoration Progress, National Research Council, supra note 4,30 .

${ }^{76} I d$., 31 (finding that numerical nutrient criteria will not contribute to the restoration of the Everglades because it does not address ditches and canals and does not cover estuaries).

${ }^{77}$ See Daniel P. Loucks, "Modeling and Managing the Interactions Between Hydrology, Ecology and Economics," Journal of Hydrology 328 (2006): 408, 415.

${ }^{78}$ See generally South Florida Natural Resource Center, supra note 5.

${ }^{79}$ See generally Alfred R. Light, supra note 51.

${ }^{80}$ See Erin Morrow, “Agri-Environmentalism: A Farm Bill for 2007," Texas Tech Law Review 38 (2006): 345, 346-347 (finding that farmers generally have a "deep love of the land" and "but for American farm policy, many farmers would be able to produce with a more ecological bent in mind").

${ }^{81}$ International Governmental Panel On Climate Change, supra note 6, 30 (noting that measured increases in sea level are consistent with the increases in temperatures).

${ }_{82}^{82}$ Id.

${ }^{83}$ Committee on Independent Scientific Review of Everglades Restoration Progress, supra note 8, 48. 
cycle. ${ }^{84}$ Despite the challenges associated with climate change, scientists have concluded that the CERP is not a futile effort provided that changing conditions are incorporated into the planning process. ${ }^{85}$

\section{ADAPTATION TO CLIMATE CHANGE}

Although efforts to mitigate climate change are essential, the IPCC has recognized the need to adapt in order to reduce risks that are certain to occur, even if the most stringent mitigation efforts are employed. ${ }^{86}$ Adapting the CERP to climate change will require a massive coordinated effort between the U.S. federal government and the state of Florida to respond to uncertainty through adaptive management. ${ }^{87}$ Successful implementation of adaptive management relies on the efficient integration of science into statutory and regulatory regimes. ${ }^{88}$ Yet predicting the specific impact of climate change on any given place is fraught with uncertainty. ${ }^{89}$ Local leaders are often concerned that uncertainty associated with climate science makes legally mandated adaptation requirements subject to political or legal challenge. ${ }^{90}$ Moreover, agencies have the propensity to use uncertainty as a tool to dodge burdensome legal requirements. ${ }^{91}$ As evidenced by contentious litigation over water quality in the Everglades, these concerns are particularly relevant in the context of adapting the CERP to climate change. Delays in implementing adaptive management, however, will make the challenge of adapting the CERP to climate change more difficult. ${ }^{92}$

Agencies charged with adapting the CERP to climate change must find compromises between stakeholders, such as sugar corporations and environmentalists. ${ }^{93}$ Towards that end, the WMD acquired a fee interest in approximately 26,800 acres of farms, with an option to buy 153,200 more

\footnotetext{
${ }^{84}$ Id.; see also Thomas H. Huntington, "Evidence for Intensification of the Global Water Cycle: Review and Synthesis," Journal of Hydrology 319 (2006): 83.

85 Committee on Independent Scientific Review of Everglades Restoration Progress, supra note 8, 53.

86 See International Governmental Panel on Climate Change, supra note 6, 65.

87 See generally Fischman and Rountree, supra note 9, 20-21.

88 See Clinton T. Moore et al., "Adaptive Management in the U.S. National Wildlife Refuge System: Science-Management Partnerships for Conservation Delivery," Journal of Environmental Management 92 (2011): 1395, 1395.

${ }^{89}$ See Fischman and Rountree, supra note 9, 43.

90 See Vicki Arroyo and Terri Cruce, "State and Local Adaptation," in eds. Gerrard and Kuh, The Law of Adaptation to Climate Change, 569.

91 Fischman and Rountree, supra note 9, 43

92 See Committee on Independent Scientific Review of Everglades Restoration Progress, supra note 8, 3 ("climate change should not be an excuse for delay or inaction in the restoration but instead provides further motivation to restore the resilience of the ecosystem"); see also Glicksman, supra note 5, 446 (emphasizing the need for adaptive measures to deal with the near-term impacts of climate change).

93 See Fischman and Rountree, supra note 9, 43.
} 
over the next ten years. ${ }^{94}$ The WMD plans to use this land to construct storm water treatment areas. ${ }^{95}$ Yet, storm water treatment areas may not be a sustainable long-term solution due to climate change. Flooding due to climate related weather would force emergency discharges of lake water in the Everglades, which can quickly overwhelm the capacity of the storm water treatment areas. ${ }^{96}$ Ultimately, the state of any wetland, such as the Everglades, is closely tied to the health of the surrounding upland environment. ${ }^{97}$ This section argues that the farm bill should be amended to subsidize efforts to plant and monitor native trees in the EAA.

\section{A. Farmers as Stewards of the Land}

The organic soils of the EAA were formed by an interaction between long hydroperiods, microorganisms, and Everglades vegetation. ${ }^{98}$ Once drained, the EAA began to experience subsidence at a rate of about one inch of soil per year. ${ }^{99}$ Although the rate of subsidence has been reduced due to legally mandated best management practices, it has not been eliminated entirely. ${ }^{100}$

${ }^{94}$ See South Florida Water Management District, Acquisition Documents: Contracts and Due Diligence, http://www.sfwmd.gov/portal/page/portal/pg_grp_sfwmd_koe/pg_sfwmd_koe_riverofgrass_acquisition (accessed April 14, 2013). The WMD originally agreed to acquire all 153,000 acres in 2008, but "economic difficulties" made this large of a purchase difficult. Instead, in 2010 the WMD purchased 26,800 acres with an option to buy the rest. Notably, the WMD has also agreed to lease 8,900 acres of the purchased land back to the farmers for $\$ 150 /$ acre/year until it "needs land for restoration 95 Id purposes." Id.

${ }^{96}$ See Light and Dineen, supra note 3, 74 (explaining that heavy rains often necessitate undesirable regulatory releases of water in the Everglades); see also Alfred R. Light, "Reducing Nutrient Pollution in the Everglades Agricultural Area through Best Management Practices," Natural Resources and the Environment 25 (Fall 2011) (describing the eutrophication of Lake Okeechobee and its potential impact on the Everglades); Debra L. Donahue, "Agriculture and Forestry," in eds. Gerrard and Kuh, The Law of Adaptation to Climate Change, 351, 352. (predicting increased erosion of topsoil from farms due to storm water runoff).

${ }^{97}$ See Paul R. Wetzel et al., "Maintaining Tree Islands in the Florida Everglades: Nutrient Redistribution Is the Key," Frontiers in Ecology and the Environment 3 (2005): 370, 370 (identifying tree islands as a critical component of the Everglades Ecosystem); see also J. M. Buttle, "Rethinking the Donut: The Case for Hydrologically Relevant Buffer Zones," Hydrological Processes 16 (2002): 3093, 3093 (reviewing the role of upland "buffer zones" in protecting the health of wetlands).

98 See Snyder and Davidson, supra note 31, 107. Frequent inundation causes anaerobic (oxygen poor) conditions, which leaves microorganisms unable to break down dead plant matter fully; over time plant matter accumulates to create deep soil. Id.

99 Id. In 1924, as part of a long term study of subsidence in the EAA, researchers drove a nine-foot-long graduated concrete post into the underlying bedrock so that the top of the post was level with the soil. In 2009 the depth of the soil at the site was 37 inches. Alan L. Wright and George H. Snyder, "Soil Subsidence in the Everglades Agricultural Area," Vegetarian Newsletter, No. 551 (Nov. 2009), http://ufdcimages.uflib.ufl.edu/UF/00/08/73/99/00541/Binder2.pdf

100 See Samira H. Daroub et al., "Best Management Practices and Long-Term Water Quality Trends in the Everglades Agricultural Area 41," Critical Reviews in Environmental Science and Technology 608 (2011) (noting that best management practices may have contributed to a decreased rate of soil subsidence). 
Likewise, best management practices have led to decreased rates of phosphorus discharge into the Everglades from the EAA, but the eutrophication of the Everglades is ongoing and is likely to result in future litigation. ${ }^{101}$ The efficacy of these measures is further complicated by the projected impacts of climate change. Farming in the Everglades is not a sustainable endeavor; once the Everglades soil subsides beyond a critical threshold, the EAA can no longer support agriculture. ${ }^{102}$ Ultimately, the practices of farmers in the EAA must evolve to deal with the reality of subsidence, stringent water quality standards, and climate change. ${ }^{103}$

One potential adaptive mechanism for farmers lies within the conservation programs of the farm bill, which is administered by the U.S. Department of Agriculture (USDA). ${ }^{104}$ The first farm bill, the Agricultural Adjustment Act, ${ }^{105}$ was passed in 1933 in response to overproduction of crops caused by overplanting and new farming innovations. ${ }^{106}$ This New Deal legislation was designed to protect the farmers' and the nations' food supply. ${ }^{107}$ What began as an attempt to stabilize crop prices and ensure continued success of small farms has morphed into a legislative package of subsidies that favor largescale corporate farming and results in environmental degradation. ${ }^{108}$ These subsidies favoring agribusiness have been maintained throughout numerous iterations of the farm bill due to the considerable political influence wielded by large corporate farms. ${ }^{109}$

In addition to the subsidies favoring corporate farming, the omnibus farm bill amendments have also created various conservation programs in an attempt to reduce environmental impacts of farming. ${ }^{110}$ The

${ }^{101}$ See $i d ., 613$.

${ }^{102}$ See Snyder and Davidson, supra note 31, 107 (explaining that EAA soil is relatively shallow and underlain by limestone bedrock).

${ }^{103}$ See $i d$. (describing the uncertain future of agriculture in the Everglades); see also Martin Reeves, et al., "Sustainability as Adaptability," Journal of Applied Corporate Finance 24 (2012): 14 ("To adapt, a company must have its antennae attuned to signals of change from the external environment, decode those signals, and then act quickly to refine or reinvent its business model and even reshape the information landscape of its industry").

${ }^{104}$ See generally Debra L. Donahue, supra note 96,361 (highlighting the potential use of the farm bill to support adaptation to climate change).

10548 Stat. 31.

106 William S. Eubanks II, “A Rotten System: Subsidizing Environmental Degradation and Poor Public Health with Our Nation's Tax Dollars," Stanford Environmental Law Journal 28 (2009): $213,219$.

107 Id. ("In essence, the 1933 Farm Bill was designed to save small farming in America and it signaled a return to the Jeffersonian ideal of an agrarian democracy").

108 Id., 223. In the 1970s, for example, the United States Department of Agriculture encouraged farmers to focus on increasing the yield of crops and increasing in size regardless of the resulting environmental degradation. These subsidies allowed large corporations to outcompete smaller operations, which has resulted in the decimation of family farming operations and the "depopulation" of rural America. Id.

${ }^{109} I d$., 229-231 (finding that corporate farms help shape the legislative process through campaign financing and other lobbying efforts).

110 See Debra L. Donahue, supra note 96, 361. 
USDA administers numerous conservation programs including the Conservation Reserve Program, ${ }^{111}$ the Wetland Reserve Program, ${ }^{112}$ the Environmental Quality Incentives Program, ${ }^{113}$ and the Wildlife Habitat Incentives Program. ${ }^{114}$

Farm bill conservation programs are often touted as an extremely effective means to incentivize farmers to pursue sustainable farming practices. ${ }^{115}$ Yet traditional commodity programs are known to undercut enrollment incentives for these conservation programs. ${ }^{116}$ For example, U.S. sugar farmers have a significantly reduced incentive to enroll in conservation programs because they profit from a number of federal sugar subsidies. ${ }^{117}$ The interaction of different farm bill provisions creates a perverse incentive for farmers to continue sugar production at the expense of both consumers and the Everglades ecosystem. ${ }^{118}$

Attempts to reform the subsidy problem in the farm bill have been met with staunch opposition. ${ }^{119}$ This is true in part because large corporate farms

11116 USC $\S \S 3831-3836$; See also Kevin C. Rigdon, "Stop the Planting! The 1985 Farm Bill, Conservation Compliance, and America's Agricultural Conservation Failure," Drake Journal of Agricultural Law 16 (2011): 487, 491. Farmers enrolled in the Conservation Reserve program agree to leave fallow highly erodible land in exchange for government payments. Id.

11216 USC $\S \S 3831-3835 \mathrm{a}$. The Wetland Reserve Program offers cost-share or easement payments to farmers that restore wetlands. See Erin Morrow, "Agri-Environmentalism: A Farm Bill for 2007," Texas Tech Law Review 38 (2006): 345, 355.

11316 USC $\S \S 3839$ aa-3839aa-9; See also 7 CFR $\S 1466.1$ ("The purposes of the Environmental Quality Incentives Program (EQIP) are to promote agricultural production, forest management, and environmental quality as compatible goals, and to optimize environmental benefits").

11416 USC $\S \S 3837-3837 \mathrm{ff}$ (providing technical and cost-share assistance for protecting wildlife habitat).

${ }^{115}$ See generally Brian J. Oakey, "The Wetlands Reserve Program: Charting a Course through the WRP," Drake Journal of Agricultural Law 8 (2003): 631, 632 (calling the Wetlands Reserve Program the "self proclaimed premier wetlands restoration program in the United States"); see also Executive Office of the President, Council on Environmental Quality, "Administration releases report on progress and next steps in restoring the Everglades, announces additional $\$ 80$ million in project funding," press release, July 13, 2012, http://www. whitehouse.gov/administration/eop/ceq/Press_Releases/July_13_2012 (announcing $\$ 80$ million in funding to establish easements on tracts of land north of Lake Okeechobee pursuant to the Wetland Reserve Program).

${ }^{116}$ See Mary Beth Blauser, "The 2008 Farm Bill: Friend or Foe to Conservationists and What Improvements Are Needed?"' Vermont Journal of Environmental Law 12 (2011): 547, 561 (describing how direct payments and non-recourse loans reward farmers for growing specified crops).

${ }^{117}$ See generally Jeff LeBlanc, supra note 45,69 . Sugar producers enjoy subsidies in the form of tariffs on imported sugar and nonrecourse loans. When the loan becomes due, farmers can chose to repay the loan or simply forfeit the crops without penalty. If the market value of sugar is less than the loan rate, farmers simply default on the loans and surrender the crops. If the market value is higher than the loan rate, sugar companies harvest the crops and sell it at a profit. Additionally, the Tariff Rate Quota restricts the importation of foreign sugar, which artificially inflates the price of domestic sugar. Id.

${ }^{118}$ See id.; see also United States General Accounting Office, "Sugar Program: Supporting Sugar Prices Has Increased User's Costs While Benefiting Producers" 20 (2000), http://www.gao.gov/archive/ 2000/rc00126.pdf

${ }^{119}$ See Melanie J. Wender, "Goodbye Family Farms and Hello Agribusiness: The Story of How Agricultural Policy Is Destroying the Family Farm and the Environment," Villanova Environmental Law Journal 22 (2011): 141, 162. 
and their employees have become dependent on farm bill subsidies to generate revenue and provide jobs. ${ }^{120}$ Moreover, for better or worse, campaign financing and industry capture appear to be a reality of our political system. ${ }^{121}$ Thus, ending the subsidies to EAA farmers would likely require significant lobbying efforts by environmentalists and may not be politically or economically feasible. I, therefore, argue that Congress should amend the farm bill to reallocate direct payments for specific crops to farmers that adopt spatially explicit adaptive management plans, such as the Everglades Custard Apple Restoration Area. This approach would likely be politically feasible for legislators that are influenced by corporate farm lobbying efforts, and provide an incentive for farmers to be active stewards of the land. In this way, sugar producers can still benefit from their subsidies while simultaneously restoring the Everglades ecosystem and increasing resilience to climate change.

In this plan farmers receive direct payments whose amount is contingent upon the current market price of the crop that would have otherwise been grown at the site. For example, each year the USDA can calculate the value of sugar per acre, and award Everglades sugar farmers that value for every acre in which they implement adaptive management. In order to qualify for the direct payment, EAA farmers would be required to hire biological consultants to plant native vegetation, ${ }^{122}$ monitor the experiment, ${ }^{123}$ and explicitly incorporate information garnered from the experiment into future management regimes. ${ }^{124}$ For example, it would be prudent to study the Everglades Custard Apple Restoration Area to ascertain the relative flood- and shade-tolerances

${ }^{120}$ See Samira H. Daroub et al., supra, note 100, 609 (noting that sugar farming in the EAA contributes $\$ 2$ billion a year to Florida's economy).

121 See, e.g., Citizens United v. Fed. Election Comm'n, 558 U.S. 310, 310 (2010) (finding that campaign financing undertaken by corporations is free speech that is protected by the First Amendment); c.f. Rachel E. Barkow, "Insulating Agencies: Avoiding Capture Through Institutional Design," Texas Law Review 89 (2010): 15 (discussing the seemingly ubiquitous problem of industry capture).

122 Planting native vegetation in the Everglades would provide an opportunity for scientists to experiment with planting different species in various densities to measure the impact on the Ecosystem. E.g., Susana L. Stoffella et al., "Survival and Growth Responses of Eight Everglades Tree Species Along an Experimental Hydrological Gradient on Two Tree Island Types," Applied Vegetation Science, 2010: 1, 2; Pamela L. Sullivan et al., "Hydrologic Processes on Tree Islands in the Everglades (Florida, USA): Tracking the Effect of Tree Establishment and Growth" Hydrogeology Journal 19 (2011): 367.

123 Everglades researchers have developed a myriad of computer models that could be employed to model the impact of the experimental planting on the Everglades ecosystem. See, e.g., Robert J. Fennema et al., "A Computer Model To Simulate Natural Everglades Hydrology," in eds. Davis and Ogden, Everglades, 249-252; see also Monica Palaseanu and Leonard Pearlstine, "Estimation of Water Surface Elevations for the Everglades, Florida," Computer and Geosciences 34 (2008): 815, 815; Fred H. Sklar et al., "South Florida: The Reality of Change and the Prospects for Sustainability: The Design of Ecological Landscape Models for Everglades Restoration," Ecological Economics 37 (2001): 379, 379; Steven R. Beissinger, "Modeling Extinction in Periodic Environments: Everglades Water Levels and Snail Kite Population Viability," Ecological Applications 5 (1995): 618.

124 See Carl J. Walters and C. S. Holling, "Large-Scale Management Experiments and Learning by Doing," Ecology 71 (1990): 2060, 2061. 
of the tree species planted. ${ }^{125}$ The vegetation and environmental variables collected as part of this research can also be used to elucidate how animals respond to environmental gradients. ${ }^{126}$ Through their efforts, farmers will be able to reduce scientific uncertainty, restore the Everglades ecosystem, and be compensated at fair market rates.

To ensure the long-term environmental benefits of this program, Everglades farmers that take advantage of the proposed farm bill provision should be required to establish a perpetual conservation easement on the tracts of land that are to be used for adaptive management. ${ }^{127}$ This would ensure that the conservation purpose of entering into the farm bill program is a permanent and worthwhile use of direct payment subsidies. Since farmers would most likely be hesitant to agree to take on the responsibility of pursuing adaptive management objectives in perpetuity, the adaptive management contracts should be on a term basis to provide sufficient flexibility. Thus, sugar farmers will continue to benefit from sugar subsidies by restoring the EAA to its historic conditions.

\section{B. Everglades Custard Apple Restoration Area}

Historically, the south shore of Lake Okeechobee, now part of the EAA, was comprised of a swamp forest dominated by custard apple (Annona glabra L.). ${ }^{128}$ The custard apple trees develop extremely large trunks and massive

125 See Caroline E. Farrior et al., "Competition for Water and Light in Closed-Canopy Forests: A Tractable Model of Carbon Allocation with Implications for Carbon Sinks," The American Naturalist 181 (2013): 314, 314 (modeling the influence of water and light on above- and below-ground tree biomass); see also Loretta L. Battaglia and Rebecca R. Sharitz, "Responses of Floodplain Forest Species to Spatially Condensed Gradient: A Test of the Flood-Shade Tolerance Tradeoff Hypothesis," Oecologia 147 (2006): 108, 108 (demonstrating that flooding, microtopography, and intraspecific competition interact to influence the spatial structure and function of forests); Rosine W. Hall and Paul A. Harcombe, "Flooding Alters Apparent Position of Floodplain Saplings on a Light Gradient," Ecology 79 (1998): $847,850-852$ (using indirect and direct gradient analyses to quantify flood- and shade-tolerance gradients).

126 See Michael W. Palmer, "Putting Things in Even Better Order: The Advantages of Canonical Correspondence Analysis," Ecology 1993: 2215 (describing the usefulness of ordination in comparing species and environmental data); see also Frank Piccininni, "The Habitat Selection of the Marbled Salamander (Ambystoma opacum): A Site Specific Approach,” (May 7, 2008; unpublished MS thesis, Marshall University) (on file with author) (using a combination of multivariate and spatial analyses to compare plant and animal data).

127 See Shea B. Airey, "Conservation Easements in Private Practice," Real Property, Trust. and Estate Law Journal 44 (2010): 745, 748. Some scholars feel that perpetual easements are not always appropriate because changed conditions reduce or eliminate the public value provided by such easements. Easements established for the purposes of restoring the Everglades, however, will increase in value by increasing the ecosystem's resilience to climate change. See Nancy A. McLaughlin, "Rethinking the Perpetual Nature of Conservation Easements," Harvard Environmental Law Review 29 (2005): 421; see also Nancy A. McLaughlin, "Conservation Easements: Perpetuity and Beyond," Ecology Law Quarterly 34 (2007): 673, 708.

128 Before the ecosystem was modified by water management, farming and human settlement, the area south of Lake Okeechobee was characterized by dense stands of custard apple and mineral rich soils 
buttressed roots. ${ }^{129}$ These features helped to protect the forest from damaging flows of water from Lake Okeechobee. ${ }^{130} \mathrm{In}$ fact, custard apple has been shown to exhibit increased growth and photosynthesis in response to flooding. ${ }^{131}$ Unfortunately, the original custard apple forest has been entirely eliminated for agricultural purposes. ${ }^{132}$

In 2002 Everglades researchers experimentally constructed tree islands in order to study the feasibility of revegetation of the Everglades. ${ }^{133}$ This experiment provided unique insights into the structure and function of vegetation in the Everglades. Once the nascent tree islands were formed, soil began to accrue (i.e., accretion), thereby improving the substrate on which the trees were originally established. ${ }^{134}$ The root structure of these planted trees also helped to maintain an increased water table relative to the surrounding marsh. ${ }^{135}$ Essentially, these young tree islands demonstrate that revegetating the Everglades can be an extremely successful endeavor. ${ }^{136} \mathrm{I}$, therefore, propose that replanting custard apple and other flood tolerant species in the EAA is an invaluable first step in adapting the CERP to the reality of climate change.

Establishing the Everglades Custard Apple Restoration Area on the south shore of Lake Okeechobee will likely increase the ecosystem's critical resilience to climate change. ${ }^{137}$ The thick growth and buttressed roots of custard apple trees can help to buffer overflow from Lake Okeechobee during extreme rainfall events, stabilize soil, and help reverse subsidence. ${ }^{138}$ Revegetation may also help to absorb nutrients and reduce eutrophication of the Everglades ecosystem, which will improve water quality and help farmers comply with the standards of the Clean Water Act. ${ }^{139}$ The Everglades Custard Apple Restoration Area can also moderate the local environment

known as "Torrey muck." Snyder and Davidson, supra note 31, 89 (describing the historical vegetation 129 Id and soils of the area directly south of Lake Okeechobee).

130 Id.

${ }^{131}$ Marcelo S. Mielke et al., "Some Photosynthetic and Growth Responses of Annona glabra L. Seedlings to Soil Flooding," Acta Botanica Brasilica 19 (2005): 905, 907.

132 Steven M. Davis et al., "Landscape Dimension, Composition, And Function In A Changing Everglades Ecosystem," in eds. Davis and Ogden, Everglades, 419-425.

133 Arnold G. van der Valk et al., "Restoring Tree Islands in the Everglades: Experimental Studies of Tree Seedling Survival and Growth," Restoration Ecology 16 (2008): 281.

134 Susana L. Stoffella et al., supra note $122,440$.

135 Id., 446.

${ }^{136}$ See van der Valk, et al., supra note 133, 281 (identifying custard apple (Annona glabra L.), Dahoon holly (Ilex cassine L.), and Carolina willow (Salix caroliniana Michx.) as the most suitable species for establishing tree islands in the Everglades).

${ }^{137}$ Custard apple, for example, is tolerant to both flooding and drought, the frequencies of which are expected to increase with climate change. See Gerhard Zotz et al., "Hydraulic Architecture and Water Relations of a Flood-Tolerant Tropical Tree, Annona glabra," Tree Physiology 17 (1997): 359.

138 See $i d$.

${ }^{139}$ Everglades tree islands have been shown to be "nutrient hotspots." Researchers believe that tree islands soil is nutrient rich partially because trees absorb phosphorus through subsurface water flows 
during drought, ${ }^{140}$ and provide critical habitat for Everglades wildlife. ${ }^{141}$

\section{CONCLUSION}

President Barack Obama, in his 2013 State of the Union Address, urged Congress to "pursue a bipartisan, market-based solution to climate change."142 One such market that can be utilized to help mitigate climate change is farming in the EAA. Research has demonstrated that trees can provide the valuable ecosystem service of carbon sequestration; ${ }^{143}$ and soils of freshwater marshes are known to be carbon sinks. ${ }^{144}$ Thus, establishing the Everglades Custard Apple Restoration Area can be viewed as both an adaptation and mitigation measure. Moreover, granting an incentive for farmers to pursue adaptive management will provide a broad array of employment opportunities for affiliated professionals such as biologists, attorneys, computer scientists, and laborers. To achieve this, the farm bill should be amended to support the Everglades Custard Apple Restoration Area. ${ }^{145}$

generated by evapotranspiration. Thus, tree islands can be effective phosphorus filters serving to remove phosphorus from the water column. See Paul R. Wetzel et al., supra note 97, 370.

140 See Steven D. Faccio, "Postbreeding Emigration and Habitat Use by Jefferson and Spotted Salamanders in Vermont," Journal of Herpetology 37 (2003): 479 (2003) (finding that canopy cover helps to moderate local temperature and maintains moist refugia).

${ }^{141}$ See Noel F. R. Snyder et al., "Reproduction and Demography of the Florida Everglades (Snail) Kite," The Condor 91: 300, 305 (detailing high nesting success rates in custard apple and Carolina willow trees relative to cattail); see also Laura A. Brandt and Frank J. Mazzotti, "Nesting of Alligators at the Arthur R. Marshall Loxahatchee National Wildlife Refuge," Florida Field Naturalist 28 (2000): 122, 123 (describing alligator nesting locations on tree islands); Randy Kautz et al., "How Much is Enough? Landscape-Scale Conservation for the Florida Panther," Biological Conservation 130: 118, 127 (using radio-telemetry to determine that forested habitat is a critical component of Florida panther habitat).

142 See Barack Obama, State of the Union Address, http://www.nytimes.com/2013/02/13/us/politics/ obamas-2013-state-of-the-union-address.html?pagewanted=all\&_r=0 (accessed April 14, 2013) ("But if Congress won't act soon to protect future generations, I will. I will direct my Cabinet to come up with executive actions we can take, now and in the future, to reduce pollution, prepare our communities for the consequences of climate change, and speed the transition to more sustainable sources of energy.").

143 See Kathryn R. Kirby and Catherine Potvin, "Variation in Carbon Storage Among Tree Species: Implications for the Management of a Small-Scale Carbon Sink Project," Forest Ecology and Management 246 (2007): 208, 214 (finding that above- and below-ground storage of carbon was significantly greater in forests than in agricultural fields).

144 Jianghus Wu et al., "Simulation of Six Years of Carbon Fluxes for a Sedge-Dominated Oligotrophic Minerogenic Peatland in Northern Sweden Using the McGill Wetland Model (MWM)," Journal of Geophysical Research Biogeosciences 118 (2013): 795; see also R. Lal, "Soil Carbon Sequestration to Mitigate Climate Change," Geoderma 123 (2004): 1.

145 C.f. Peter H. Gleick et al., "Letters: Climate Change and the Integrity of Science," Science 328 (2010): 489, 489-490 ("Society has two choices: We can ignore the science and hide our heads in the sand and hope we are lucky, or we can act in the public interest to reduce the threat of global climate change quickly and substantively. The good news is that smart and effective options are possible. But delay must not be an option."). 


\section{ACKNOWLEDGMENTS}

The author would like to extend his gratitude to Professor Katrina F. Kuh whose comments and insights greatly improved the form and substance of this article. Additionally, thank you to Professor Courtney L. Selby for assistance in ferreting out historical legal citations. Finally, thank you to Kristin Perret for tirelessly reviewing numerous drafts of this article. 